University at Buffalo School of Law

Digital Commons @ University at Buffalo School of Law

\title{
In Search of Sub-National Constitutionalism
}

James A. Gardner

University at Buffalo School of Law

Follow this and additional works at: https://digitalcommons.law.buffalo.edu/journal_articles

Part of the Comparative and Foreign Law Commons, and the Constitutional Law Commons

\section{Recommended Citation}

James A. Gardner, In Search of Sub-National Constitutionalism, 4 Eur. Const. L. Rev 325 (2008).

Available at: https://digitalcommons.law.buffalo.edu/journal_articles/231

This article has been published in a revised form in European Constitutional Law Review 10.1017/ S1574019608003258. This version is free to view and download for private research and study only. Not for redistribution, re-sale or use in derivative works. (C) Asser Press 2008

\section{IN COPYRIGHT}

This Article is brought to you for free and open access by the Faculty Scholarship at Digital Commons @ University at Buffalo School of Law. It has been accepted for inclusion in Journal Articles by an authorized administrator of Digital Commons @ University at Buffalo School of Law. For more information, please contact lawscholar@buffalo.edu. 


\title{
IN SEARCH OF SUBNATIONAL CONSTITUTIONALISM
}

\author{
James A. Gardner \\ State University of New York \\ University at Buffalo Law School \\ Buffalo, NY 14260 \\ jgard@buffalo.edu \\ Draft: September 19, 2007
}

Originally prepared for Seventh World Congress, International Association of Constitutional Law Athens, Greece, June 11-15, 2007 


\begin{abstract}
Two recent trends, one favoring federalism as a form of governmental organization and the other favoring written constitutions, have lately combined to produce an impressive proliferation of subnational constitutions. Documents that can fairly be described as constitutions now govern the affairs of subnational units - states, provinces, cantons, Länder - in federal states on every continent. What remains unclear, however, is whether the proliferation of subnational constitutions indicates a corresponding spread of the practice of subnationalism constitutionalism - whether, that is, the appearance of subnational constitutions around the globe evinces a spreading ideological commitment to a strong role for subnational governments in shaping the lives, and protecting the liberty, of citizens of federal states. This paper examines some aspects of the context and conditions in which subnational constitutions have emerged and finds the evidence mixed. On one hand, the rise of ethnocultural self-determination as a justification for federalism, and the presence in many subnational constitutions of provisions directly protecting human rights, are consistent with an ideology of subnational constitutionalism. Other considerations, however, tend to undermine the possibility of a thriving subnational constitutionalism. These include the ready availability of national constitutional politics as a forum for resolving significant social and political questions; the practice in many parts of the world of resorting to extraconstitutional politics to resolve fundamental issues of governance and identity; the rise, especially in Europe, of subsidiarity as the prevailing political theory of subnational power; and the growing emphasis around the globe on supranational and international regimes as primary protectors of human rights.
\end{abstract}


Since the end of the Second World War, federalism has emerged as one of the most popular forms of government in the world, employed today in more than two dozen nations populated by one-third of the world's inhabitants. ${ }^{1}$ One of the defining attributes of federalism is of course the autonomy it grants to subnational units - states, provinces, cantons, Länder, and so on - and by far the most important way in which subnational autonomy manifests itself is in the authority of subnational units to govern themselves with some degree of independence from rules and policies established at the national level.

At the same time, it has become commonplace for autonomous, democratically self-governing populations to adopt rules and principles for their own collective self-governance in the form of a constitution. As a result, the spread of federalism has, perhaps predictably, been accompanied by a proliferation of subnational constitutions. Today, documents that can fairly be described as constitutions govern the affairs of subnational divisions of nations on every continent. Among nations in which federalism is the prevailing form of governmental organization, all the Australian states, Austrian and German Länder, Swiss cantons, and American states have their own constitutions. States and provinces in Argentina, Brazil, Ethiopia, Malaysia, and Mexico have adopted constitutions, as have subnational units in Russia, Spain, and the United Kingdom. One South African province, one Indian state, and even one Canadian province have formally adopted written constitutions.

While it is clear that the spread of federalism has been a precondition for the spread of subnational constitutions, it is less clear what the recent flowering of subnational constitutions signifies about the global practice of constitutional self-governance. In particular, the interesting

1 Ronald L. Watts, States, Provinces, Länder, and Cantons: International Variety among Subnational Constitutions, 31 Rutgers L.J. 941, 942 (2000). 
question for constitutional law is whether the proliferation of subnational constitutions indicates a corresponding proliferation of the practice of subnationalism constitutionalism - whether, that is, the appearance of subnational constitutions around the globe evinces a spreading ideological commitment to a strong role for subnational governments in shaping the lives, and protecting the liberty, of citizens of federal states.

In this paper, I begin to explore this question by examining some aspects of the context and conditions in which subnational constitutions have appeared. The evidence, I conclude, is mixed. Although some signs of subnational constitutionalism may be found in the recent efflorescence of state and provincial constitutions, there are also reasons to be cautious about inferring that the presence of subnational constitutions reveals a corresponding spread of the ideology of constitutionalism at the subnational level.

\section{Subnational Constitutionalism}

Although the term "constitutionalism" has many meanings, it is unnecessary for present purposes to distinguish finely among them because they all point more or less toward the same general idea, one well captured in U.S. Chief Justice John Marshall's famous dictum, issued

nearly two centuries ago: "we must never forget that it is a constitution we are expounding."2

On this view, a constitution is fundamentally different from other legal documents, and the main point of difference lies in the purpose for which it is adopted. According to a widely accepted political theory typically associated with constitutionalism, a constitution is understood to be a document deliberately created by a society for its own self-governance which expresses that 
society's fundamental desires about how it ought to live. ${ }^{3}$ Because on this view a constitution is a kind of charter for living, it therefore necessarily reflects the beliefs of the people who make it about the nature of a good life, both for the self-governing community that the constitution directly governs, and for the individuals who inhabit it. A second aspect of constitutionalism, highly prominent in the American branch of the tradition, refers even more particularly to the belief that a paramount goal of collective self-governance is the protection of liberty, and that a critically important function of any constitution is therefore to create institutions capable of protecting popular liberty against incursions by government. ${ }^{4}$

3 See James A. Gardner, The Failed Discourse of State Constitutionalism, 90 Mich. L. Rev. 761, 814-17 (1992).

$4 \quad$ See The Federalist, No. 51, at 322 (James Madison) (Clinton Rossiter, ed. 1961): "If men were angels, no government would be necessary. If angels were to govern men, neither external nor internal controls on government would be necessary. In framing a government which is to be administered by men over men, the great difficulty lies in this: you must first enable the government to control the governed; and in the next place oblige it to control itself." 
Subnational constitutionalism is nothing more than the application of the principles of constitutionalism at the subnational level. An ideology of subnational constitutionalism accordingly conceives of state, provincial, or regional constitutions as charters of self-governance self-consciously adopted by subnational populations for the purpose of achieving a good life by effectively ordering subnational governmental power and by protecting the liberties of subnational citizens. For example, an ideology of subnational constitutionalism clearly guided the Texas Supreme Court when it claimed in a 1992 case that the Texas Constitution must be understood, unlike the U.S. Constitution, to "'reflect Texas' values, customs, and traditions,'" and must therefore be interpreted in view of the "experiences and philosophies" of the state's founders, whose beliefs about self-governance were shaped by "years of rugged experience on the frontier." 5

The main point for present purposes is simply that an ideology of subnational constitutionalism conceives of subnational units as having an independent role - a role of constitutional stature - in the collective self-governance of a nation. This would mean, typically, that subnational units are, in the words of the U.S. Supreme Court, "not mere political subdivisions of the [nation], and state governments are neither regional offices nor administrative agencies of the federal government."6 Instead, subnational units have a degree of autonomy sufficient to make them efficacious representatives and agents of subnational populations, and their constitutions meaningful documents of self-governance that provide to some significant

\footnotetext{
Davenport v. Garcia, 834 S.W.2d 4, 16 (Tex. 1992), quoting LeCroy v. Hanlon, 713 S.W.2d 335, 339 (Tex. 1986).

$6 \quad$ New York v. United States, 505 U.S. 144, 158 (1992).
} 
degree for independence from processes of self-governance employed at the national level by the national polity.

Because subnational constitutionalism forms the matrix for what is in essence a legal culture, ${ }^{7}$ its presence cannot really be detected without a correspondingly wide-ranging inquiry into the constitutional culture of the place in question. It is unlikely, for example, that the existence of subnational constitutionalism can reliably be inferred from an examination of constitutional texts alone. Nevertheless, constitutional texts can certainly furnish useful evidence of subnational constitutionalism. Two types of evidence could be of particular value, both having to do with the potential capacity of subnational constitutions to protect the liberty of subnational citizens.

Within a federal system, subnational constitutions might protect liberty in one of two ways. First and most obviously, subnational constitutions might protect liberty directly, through the identification and explicit protection of human rights in a charter of rights or its equivalent. Second, subnational constitutions might protect liberty indirectly, by granting subnational governments affirmative powers sufficient to permit them to shield their citizens from abuses of centralized power at the national level.

7

Daniel S. Lev, Social Movements, Constitutionalism and Human Rights: Comments from the Malaysian and Indonesian Experiences, in Douglas Greenberg, et al., eds. Constitutionalism and Democracy: Transitions in the Contemporary World (1993). 
This second, indirect method of subnational liberty protection is most closely associated with the justification for U.S. federalism articulated by James Madison. "The accumulation of all powers . . . in the same hands," wrote Madison in Federalist No. 47, "may justly be pronounced the very definition of tyranny." 8 To protect liberty, on this view, power must be divided. Federalism serves this purpose by parceling out government powers among different levels of government, giving each level of government, national and subnational, powers sufficient to allow each to monitor and check the abuses of the other. ${ }^{9}$ Although power is fragmented in such a system, its use is ultimately unified because each level of government pursues the same goal: serving the interests of the people. ${ }^{10}$ As Madison put it, "[t]he federal and State governments are in fact but different agents and trustees of the people, constituted with different powers and designed for different purposes." ${ }^{11} \quad$ Federalism, on this model, is thus a dynamic system designed to be manipulated by the people to produce results they desire.

Madison's co-author Alexander Hamilton put this point clearly:

[I]n a confederacy the people, without exaggeration, may be said to be entirely the masters of their own fate. Power being almost always the rival of power, the general government will at times stand ready to check the usurpations of the state governments, and these will have the same disposition towards the general government. The people, by throwing themselves into the scale, will infallibly make it preponderate. If their rights are invaded by either, they can make use of the other as the instrument of redress. ${ }^{12}$

\footnotetext{
8 The Federalist, No. 47, at 301 (James Madison) (Clinton Rossiter, ed. 1961).

$9 \quad$ Andrzej Rapaczynski, From Sovereignty to Process: The Jurisprudence of Federalism after Garcia, 1985 Sup. Ct. Rev. 341, 380-95.

10 Vincent Ostrom, The Political Theory of a Compound Republic 23 (1987).
11 The Federalist, supra, No. 46 (Madison), at 294.
12 The Federalist, supra, No. 28 (Hamilton), at 180-81. See also id., No. 46 (Madison), at 295, in
} 
On the Madisonian view of federalism, then, popular allegiance to any government is not organically fixed, but rather will ebb and flow according to that government's instrumental value to the populace at any given time. Federalism therefore does not define a static relation among national and subnational governments, but a living, dynamic one, and subnational governments must accordingly have sufficient autonomy and power to hold up their end of the bargain.

which Madison, after remarking that Americans place their faith and trust primarily in their state governments, observes: "If . . . the people should in future become more partial to the federal than to the State governments, the change can only result from such manifest and irresistable proofs of a better administration as will overcome all their antecedent propensities. And in that case, the people ought not surely to be precluded from giving most of their confidence where they may discover it to be most due ...." 
This analysis suggests that the presence of subnational constitutions need not imply the presence of subnational constitutionalism. Just as it is possible to have what Jan Erk refers to as a "federation without federalism,"13 so it is possible to have a constitution without constitutionalism. ${ }^{14}$ A subnational constitution that neither embodies the values of the populace that framed and adopted it, nor establishes for the subnational government any significant role in the direct or indirect protection of the liberty of subnational citizens, is not likely to be a document that draws upon an underlying popular ideology of constitutionalism. For example, a subnational constitution that does nothing more than formalize the administrative subordination of the subnational to the national government would lack the qualities that indicate an underlying popular commitment to subnational constitutionalism.

That constitutions and constitutionalism are conceptually independent is further demonstrated by the phenomenon of subnational constitutionalism without constitutions, of which Canada presents the clearest example. There, Canadian provinces understand themselves to be political actors of the first rank, yet (with the single exception of British Columbia) govern themselves, following the British tradition, by unwritten constitutions. ${ }^{15}$ For these reasons, any

13 Jan Erk, Austria: A Federation without Federalism, 34 Publius 1 (2004). Erk's title refers to the high degree of centralization found in Austrian federalism, an arrangement that renders Austrian Länder nothing more than "administrative units in a decentralized state rather than retaining their position as the constituent members of a federal union." Id. at 1.

14 See, e.g., H.W.O. Okoth-Ogendo, Constitutions without Constitutionalism: Reflections on an African Political Paradox, in Douglas Greenberg, et al., eds., Constitutionalism and Democracy (Oxford 1993) regarding national constitutions, and Ivo D. Duchacek, State Constitutional Law in Comparative Perspective, 496 Annals of the Am. Acad. of Pol. and Soc. Sci 128 (1988), regarding subnational constitutions.

15 Nelson Wiseman, Clarifying Provincial Constitutions, 6 National Journal of Constitutional Law [Canada] 269 (1996); Campbell Sharman, The Strange Case of a Provincial Constitution: The British Columbia Constitution Act, 17 Canadian Journal of Political Science 87 (1984). 
inquiry into the existence of subnational constitutionalism requires a detailed examination of the constitutional culture of the place under study. Although such an examination is well beyond the scope of this paper, it is possible to prepare the ground by attention to some of the more commonplace conditions in which contemporary subnational constitutions have been adopted and in which they operate.

\section{Signs of Subnational Constitutionalism}

It is easy, and for Americans undoubtedly quite natural, simply to assume that federalism implies subnational constitutionalism - that subnational constitutionalism, in other words, is in some sense an inevitable consequence of the creation of a genuinely federal system of governance in which subnational units possess the authority to draft and adopt their own constitutions. I consider below at least four reasons why this might be the case. The first possibility, and the one that represents the strongest claim, is that federalism by definition gives rise to subnational constitutionalism. A second and somewhat more restrained claim is that the U.S. experience with federalism demonstrates that federalism is capable of producing subnational constitutionalism, and that the U.S. experience can be extrapolated to support the conclusion that federalism empirically generally does produce subnational constitutionalism, even though no theoretical imperative so requires. Third, increasingly prevalent ethnocultural justifications for federalism may suggest that subnational constitutions often, or even typically, reflect distinctive values and choices of subnational populations, a situation consistent with the widespread existence of subnational constitutionalism. The fourth and mildest claim is that the characteristics of at least some actual subnational constitutions in federal states demonstrate the 
existence of subnational constitutionalism in those states. I take up each of these possibilities in turn.

Subnational constitutionalism as an inherent consequence of federalism. It is possible that federalism, properly understood, operates in such a way that the creation of a subnational constitution in a federal system inherently reflects the presence of subnational constitutionalism. The absolute minimum function of a subnational constitution, like any other constitution, is to create and order subnational power by defining and authorizing it, and establishing constraints on its use. In so doing, a subnational constitution necessarily establishes a framework for the practice of self-governance by the subnational population to which it applies. However, the creation of a constitution at the subnational level also inevitably does something else: it contributes to the construction of a relationship between national and subnational power, and by extension to a relationship between the national and subnational populations whose governments exercise such powers. These actions, one might then say, are inherently constitutive of a subnational identity, and it follows that a well-drafted subnational constitution therefore will inevitably express to some degree the beliefs and aspirations of the people of the subnational unit, and their conclusions about how their liberties ought best to be protected.

To this it might be responded that there is nothing in the adoption of a subnational constitution that necessarily transforms it into either the matrix of an independent subnational political identity, ${ }^{16}$ or the source of mechanisms for protecting liberty above and beyond those provided nationally. A subnational constitution might, for example, authorize the subnational

\footnotetext{
16 Some of the complications in such a view are spelled out in greater detail in James A. Gardner, Whose Constitution Is It? Why Federalism and Constitutional Positivism Don't Mix, 46 Wm \& Mary L. Rev. 1245 (2005).
} 
unit to do nothing more than administer locally a set of laws and norms generated at the national level - to serve, that is, as a local agent of the central government. Numerous provisions of actual subnational constitutions follow such a pattern. The constitution of Austria, for example, expressly requires that policies created by the national government be implemented by the executive authorities of the Länder. Article 102(1) provides that, in the absence of a dedicated federal bureaucracy, Land authorities "exercise the executive power of the Federation." Article 103(1) goes even further by explicitly subordinating Land power to national power: "In matters of indirect Federal administration the Land Governor is bound by the instructions of the Federal Government as well as the individual Federal Ministers . . . and he is obligated, in order to effect the implementation, to employ also the means which are at his disposal in his capacity as an organ of the independent area of operation of the Land."17 These provisions thus make Land governments mere agents of the central government in areas of national competence.

One possible response to this argument is that a nation in which subnational units lack the authority to do anything more than implement central directives of the national government is not truly federal. Its subnational units by definition lack the autonomy that a meaningfully federal system requires, making decentralization in such a government indistinguishable from the kind of administrative hierarchy found routinely in unitary states. This conclusion, however, is circular; it presupposes an inherent relationship between federalism and subnational constitutionalism, yet

17 The Federal Constitutional Law of 1920 (Austria), Arts. 102(1), 103(1). Such a requirement would clearly violate the U.S. Constitution, as the Supreme Court held in Printz v. United States, 521 U.S. 898 (1997), in which it established an "anti-commandeering" principle under which the national government is forbidden from conscripting state executive officials into national service. Nothing in this doctrine, however, forbids states from voluntarily consenting to implement federal law, and they frequently do so. Most U.S. social welfare programs, for example, are administered in this way. 
recognizes as federal only those states in which the conditions for subnational constitutionalism can be shown to exist. This of course proves the hypothesized relationship, but only by definitional fiat, limiting its analytic utility. ${ }^{18}$

The experience of the United States. Even if there is no necessary theoretical connection between federalism and subnational constitutionalism, it is possible that a contingent relationship exists that is nevertheless robust across a variety of circumstances. The experience of the United States demonstrates that subnational constitutionalism can in practice accompany federalism, raising the possibility that the latter can induce the former.

18 It has even been suggested that federalism does not even presuppose national constitutionalism. See J.H.H. Weiler, Federalism without Constitutionalism: Europe's Sonderweg, in Kalypso Nicolaidis and Robert Howse, eds., The Federal Vision: Legitimacy and Levels of Government in the United States and the European Union (Oxford 2001). 
Subnational constitutionalism unquestionably exists to some degree in the American system of federalism. Although I do not believe that contemporary American subnational constitutions express or reflect distinct subnational identities, ${ }^{19}$ the American states have without a doubt frequently seen themselves, and been seen by their inhabitants, as important, autonomous, and often effective defenders of the local citizenry against abuses of power by the national government. As Madison anticipated, U.S. states have a long record of inserting themselves between their citizens and Washington, and of deploying powers assigned to them by their subnational constitutions in ways intended quite self-consciously to thwart the operation of national policies that they have determined to be destructive of their citizens' liberties. From the Virginia and Kentucky Resolutions of 1798, which loudly protested the national government's suppression of political criticism, to recent lawsuits filed by states to challenge national regulatory authority, U.S. states have from time to time deployed their constitutional authority in numerous ways to defend their citizens from perceived abuses of national power. ${ }^{20}$

19 See James A. Gardner, Interpreting State Constitutions: A Jurisprudence of Function in a Federal System (Chicago: University of Chicago Press 2005), ch. 2; James A. Gardner, Southern Character, Confederate Nationalism, and the Interpretation of State Constitutions: A Case Study in Constitutional Argument, 76 Tex. L. Rev. 1219 (1998).

\footnotetext{
20 These and many other incidents are described in Gardner, Interpreting State Constitutions, supra note _, ch. 3 .
} 
Furthermore, the existence in the United States of a dual judicial system, in which both national and subnational governments possess independent constitutional courts, has created an occasionally robust form of "dialogic" federalism in which actors in each judicial system engage in a kind of ongoing conversation with one another about the meaning and content of constitutionally guaranteed liberties. ${ }^{21}$ From time to time disagreements have erupted among state and national courts, and these disagreements have sometimes resulted in alterations of constitutional doctrine not only at the subnational level, where state courts often follow the national lead, but also at the national level, notwithstanding the formal supremacy of national constitutional law. ${ }^{22}$

Of course, the fact that subnational constitutionalism arose in the United States does not necessarily mean that it will be found in other federal states. In Part III, I suggest some reasons why conditions elsewhere may differ in salient ways.

21 Lawrence Friedman, The Constitutional Value of Dialogue and the New Judicial Federalism, 28 Hastings Const. L. Q. 93 (2000); Paul W. Kahn, Interpretation and Authority in State Constitutionalism, 106 Harv. L. Rev. 1147 (1993).

22 Although state courts more often conform their own interpretations of state constitutions to interpretations of the federal constitution made by federal courts (often known as "lockstep" analysis), see, e.g., Robert F. Williams, State Courts Adopting Federal Constitutional Doctrine: Case-by-Case Adoptionism or Prospective Lockstepping?, 46 Wm. \& Mary L. Rev. 1499 (2005), the U.S. Supreme Court has occasionally been influenced by a reciprocal process. See Mapp v. Ohio, 367 U.S. 643 (1961); Lawrence v. Texas, 539 U.S. 558 (2003). 
Ethnocultural self-determination as a justification for federalism. Modern accounts of federalism have gone well beyond Madison to broaden substantially the range of considerations accepted as justifications for the creation of a federal structure of governance. ${ }^{23}$ One of the most prominent of these justifications holds that federalism is desirable because of its capacity to permit some degree of self-determination to ethnoculturally distinctive subgroups when they are geographically concentrated. ${ }^{24}$

As federalism has spread around the globe, ethnocultural self-determination has increasingly been invoked as a justification for adoption of a federal system. Such reasoning has long played a role in Canadian debates about the status of Quebec, for example, but it also provides the main justification for the more recent adoption in Spain of devolutionary Estatutos de Autonomía, an action taken mainly in response to demands for self-determination by Basque and Catalonian subpopulations. Claims of ethnocultural pluralism have played a role in shaping federalism in Belgium, Bosnia, India, Nigeria, Russia, Switzerland, and even the United Kingdom, among others.

The justification of federalism as a vehicle to provide self-determination to ethnocultural subgroups resonates strongly with the conceptual foundations of subnational constitutionalism. If a constitution is in some sense an expression of the beliefs of a self-governing populace as to how its members ought to live, and some ethnocultural groups see themselves as sufficiently distinct from the national populations among whom they reside to justify some form of

\footnotetext{
23 See, e.g., Thomas Dye, American Federalism (1990).

24 See generally G. Alan Tarr, Robert F. Williams, and Josef Marko, eds., Federalism, Subnational Constitutions, and Minority Rights (Westport, Connecticut: Praeger 2004).
} 
subnational self-determination, then any subnational constitution such a group creates for itself might be very likely to reflect the distinctive traits that by hypothesis entitle the group to political self-determination in the first place. Ethnocultural justifications for federalism thus may lend plausibility to the premises of subnational constitutionalism.

The characteristics of actual subnational constitutions. Subnational constitutionalism rests on the premise that an important purpose of subnational constitutions is the direct or indirect protection of liberty through the independent agency of subnational power. Many existing subnational constitutions contain provisions that are clearly intended to specify and protect the rights of subnational populations in ways that are consistent with the premises of subnational constitutionalism.

The most direct and obvious method of protecting rights in subnational constitutions is through express specification in a charter or declaration of rights. In Argentina, for example, the provincial constitution of Buenos Aires provides specific protections for private religious freedoms. ${ }^{25}$ The Argentine provincial constitution of Jujuy specifically recognizes a host of rights including rights to dignity, life, personal integrity, health, equality, speech, and many others. $^{26}$ In Germany, the Land constitution of Bavaria expressly protects rights of human dignity, personal freedom, private property, conscience, speech, and press, among others. ${ }^{27}$ The constitution of North Rhine-Westphalia provides express protection for rights of religious

25 Constitution of the Province of Buenos Aires, Arts. 7, 8.

26 Constitution of Province of Jujuy (Argentina), Arts. 18-42.

27 Constitution of the Free State of Bavaria (Germany), Arts. 98-118. 
association and the right to work. ${ }^{28}$ The constitutions of the Swiss cantons of Geneva and Lucerne both guarantee rights of equality, property, religion, and free speech. ${ }^{29}$

28 Constitution of the State of North Rhine-Westphalia (Germany), Arts. 19, 24.

29 Constitution of the Republic and Canton of Geneva (Switzerland), Arts. 2-11; Constitution of the Canton of Lucerne, Arts. 2-9. 
Interestingly, provisions found in subnational declarations of rights often duplicate protection for rights entrenched in the national constitution. The above-mentioned rights of religious liberty guaranteed by the Argentine provincial constitutions of Buenos Aires and Jujuy, for example, seemingly duplicate provisions found in Article 14 of the Argentine Constitution. ${ }^{30}$ Bavarian constitutional protections for human dignity, freedom of action, and freedom of the person replicate similar protections provided in the German Basic Law. ${ }^{31}$ Numerous subnational constitutions appear to provide duplicate protection for entire sets of nationally guaranteed rights that are simply incorporated by reference. The constitution of the Mexican state of Baja California, for example, provides that the rights of "inhabitants of the State [are] those granted by the General Constitution of the Republic . ..."32 The constitutions of Spain's subnational regions similarly tend to incorporate by reference rights established nationally; Catalonia's provision, which is typical, provides: "The citizens of Catalonia have the fundamental rights and duties that are set out in the national Constitution." 33

\footnotetext{
Constitution of the Argentine Nation, Art. 14.

31 Compare Constitution of the Free State of Bavaria (Germany), Arts. 100-102, with Basic Law for the Federal Republic of Germany, Art. 1(1), 2(1), 2(2).

32 Political Constitution of the Free and Sovereign State of Baja California (Mexico), Art. 8.

33 Statute of Autonomy of Catalonia (Spain), Art. 8(1).
} 
Duplicate protection of rights at the national and subnational levels might well provide evidence, where it occurs, of subnational constitutionalism. Where a supreme national constitution already provides express protection for some kind of right, protection of the same right in a subnational constitution appears at first glance to be superfluous. In the United States, where such duplication occurs with some frequency, the best explanation seems to be that subnational units intend thereby to assert a kind of simultaneous jurisdiction over the protection of the rights in question. Subnational units, in other words, do not simply cede to the national government responsibility for protecting the duplicated right, for it is always possible that the national government will fail to protect the right with sufficient vigor. If the subnational unit possesses independent authority to protect the same right, then it may be able to fill any void left by a failure of national power or national will. ${ }^{34}$ Such a relationship between national and subnational power seems to reflect the workings of a Madisonian subnational constitutionalism. It suggests that subnational units understand themselves not only as independent agents for the protection of popular liberty, but, at least potentially, as competitors with the national government for popular allegiance based on the effective performance of the function of protecting human rights. Functional Theory of State Constitutions, 91 Geo. L.J. 1003 (2003). 
Many constitutional systems around the world also create the conditions under which subnational units may protect the liberty of citizens indirectly, through the affirmative exercise of granted powers. This may occur most commonly where national and subnational areas of competence overlap, i.e., there are areas of shared competence. For example, Article 74 of the German constitution establishes concurrent legislative competence of the federal and Land governments over criminal law, public welfare, economic affairs, labor, and many other areas. ${ }^{35}$ Title III of the Swiss constitution establishes concurrent legislative competence of the confederal and cantonal governments in numerous areas, including culture, the environment, natural resources, energy policy, and economic affairs, among others. ${ }^{36}$

Concurrent competence creates the conditions for competition between national and subnational governments even where national law is supreme. This is because a grant of concurrent authority often permits subnational governments to enter fields in which the national government has failed to act, or acted incompletely, or irresponsibly, or counterproductively, in an effort to correct the damage. Consider environmental regulation, for example. If a national government fails to use its power to protect the environment in ways that are necessary to fulfill popular interests or protect popular rights to health or to a clean environment, a subnational government with concurrent authority in the area may enact legislation that the national government has failed to enact, or may supplement weak national measures with stronger ones that better comport with the wishes of the subnational population whose interests it has a duty to protect.

35 Basic Law for the Federal Republic of Germany, Art. 74.

36 New Constitution of the Swiss Federation, Arts. 69, 74, 89, 94. 
In short, the distribution of constitutional powers into overlapping spheres provides some evidence of a structure that is in principle capable of supporting a robust subnational constitutionalism, although the presence of a such a structure may not be sufficient, by itself, to produce subnational constitutionalism.

\section{Why Subnational Constitutionalism May be Rarer than It Seems}

Up to this point, I have indicated several grounds upon which one might plausibly think that in many places around the globe the conditions for subnational constitutionalism exist. Whether it has in fact arisen in such places, however, is another question. That the conditions exist says nothing about actual subnational constitutional practices - how subnational power is conceived by citizens, how it is deployed by governmental actors, and how it functions within the federal structure of any particular national constitutional system. Consequently, to determine whether a genuine and robust subnational constitutionalism exists in any particular place requires answering challenging empirical questions that are far beyond the scope of this paper. ${ }^{37}$

I shall therefore pursue in the balance of the paper the much more modest goal of suggesting some reasons for caution in concluding that the appearance of subnational constitutions in a federal state implies the appearance of subnational constitutionalism. In particular, I discuss below five such reasons: (1) the easy availability of national constitutional politics as a vehicle for resolving questions of social and political significance; (2) the practice of resorting to extraconstitutional politics instead of law to resolve fundamental issues of

37 Investigating such questions is made particularly difficult by the limited availability in translation of subnational constitutions, and the even more limited availability of translations of national or subnational judicial decisions construing such constitutions. 
governance and identity in many parts of the world; (3) the rise, especially in Europe, of subsidiarity as the prevailing political theory of subnational power; (4) the growing emphasis in many parts of the world on supranational and international regimes as primary protectors of human rights; and (5) the lack of dual judicial systems in many federal states.

Easy access to national constitutional politics. With the notable exception of the United States, the national constitutions of the world's federal states have been adopted only recently. Switzerland, for example, adopted its current national constitution in 1998, Ethiopia did so in 1995, Argentina in 1994, Russia in 1993, Brazil in 1988, Spain in 1978, India in 1950, Germany in 1949, Austria in 1920, and Mexico in 1917. ${ }^{38}$ The older of these constitutions have, moreover, been amended with some frequency - the German constitution more than fifty times and the Austrian and Mexican constitutions hundreds of times ${ }^{39}$ - and some of these amendments have been far from trivial. The national constitutions of Germany and Spain, for instance, were amended in 1992 to reflect membership in the European Union (EU), a major constitutional change involving significant alterations to fundamental aspects of national power. $^{40}$ Finally, a fair number of recent amendments to national constitutions have dealt specifically with the respective competencies of national and subnational governments. The German Basic Law, for example, has been amended on several occasions to make extremely fine constitution. In some cases, the original version of the constitution at issue is much older than the most recently adopted version. I thank Walter Carnota for bringing this point to my attention.

39 For a comparative overview of amendment rates of national constitutions, see Donald S. Lutz, Toward a Theory of Constitutional Amendment, in Sanford Levinson, ed., Responding to Imperfection: The Theory and Practice of Constitutional Amendment (Princeton 1995), at 261, Table 11.

40 Similarly significant changes have been made to the German constitution upon reunification in 1990 and to conform to a series of multinational defense treaties, including NATO. 
adjustments in the reach of concurrent powers, such as a 1959 amendment adding the production of nuclear energy to the list of concurrent powers, and a 1971 amendment extending concurrent power to the terms of employment of certain public employees. ${ }^{41}$

All this constitutional adoption and amendment activity suggests that national constitutional politics is, in most federal states, a readily available and highly responsive forum in which a polity may work out answers to important questions of constitutional significance questions of the scope of civil liberties, for example, or of the proper allocation of authority between national and subnational governments. National constitutions are thus likely to reflect with some accuracy the most recent thinking of the national polity, and to institutionalize that thinking directly in the terms and provisions of constitutional law. 
Indeed, in this respect, national constitutional politics in most federal states bears a striking resemblance to subnational constitutional politics in the United States. In the U.S., replacement of the national constitution with a more contemporary model is simply unthinkable, and constitutional amendment is made so difficult both by procedural requirements and by the rise of a kind of culture of constitutional veneration, that resort to national constitutional politics is virtually never a realistic option for addressing fundamental social and political questions. In contrast, American subnational constitutions are frequently discarded and replaced, and even more frequently amended, so that they are far more likely than the national constitution to reflect contemporary views about how important issues should be resolved. ${ }^{42}$

This difference may be significant for subnational constitutionalism because it suggests that, outside the United States, subnational constitutions are not very likely to serve as important forums for working out difficult policy questions. Because questions concerning the structure and content of government power, and of the allocation of power between levels in a federal system, are routinely and readily addressed in the forum of national constitution-framing and -amendment, any pressure to address these questions in subnational constitutions is likely to be correspondingly reduced. And a constitution that does not serve as a vehicle for registering and pursuing the deeply held goals of a subnational polity is unlikely to become the focal point of a robust constitutionalism.

42 G. Alan Tarr, Understanding State Constitutions (Princeton, N.J.: Princeton University Press 1998). 
Politics as a first resort. If easy and frequent resort to national constitutional politics has the potential to undermine subnational constitutionalism by making subnational constitutions largely irrelevant to the resolution of pressing public issues, resort with any kind of frequency to a politics entirely outside of constitutional parameters would do so all the more because it would make all constitutions irrelevant, at any level. Many contemporary federal states bear the marks of an unfortunate history of extraconstitutional politics in the form of coups, military rule, and the exercise of de facto government power during which existing, formal constitutional structures were retained, but essentially ignored. Argentina, for example, endured six coups between 1930 and 1983. Brazil adopted its present constitution following more than twenty years of military rule. In Mexico, centralized party dominance of the political system subverted operation of formal constitutional mechanisms for at least six of the nine decades since its adoption. ${ }^{43}$ Constitutional mechanisms in Nigeria and Venezuela have from time to time existed more on paper than in practice.

Although all these states are federal, in none of them has subnational power played any effective role in resisting usurpations of power occurring at the national level. Instead, significant decisions about how the peoples of these nations are to live have been made in the forum of a politics that is both national and extraconstitutional. As a result, subnational populations within these nations might reasonably possess little faith in subnational constitutionalism - or even national constitutionalism - as a useful forum in which to pursue their aspirations for good self-governance.

43 José Gamas-Torruco, The Presence of the Federal System in Mexico, 44 Duquesne L. Rev. 35 (2005). 
But it is not only the extraconstitutional practice of politics that has the potential to undermine subnational constitutionalism. In some federal states, the national constitution itself provides that relations between governments may be settled through political negotiation rather than constitutional rule. Perhaps the most notable instance of this practice appears in Article 66 of the Russian constitution, which provides: "The status of a subject of the Russian Federation may be changed by mutual agreement between the Russian Federation and the subject of the Russian Federation in accordance with a federal constitutional law."44 Under this provision, subnational governments may negotiate freely with the national government to determine the degree of autonomy that the subnational unit will enjoy, and the nature of national-subnational relations. $^{45}$ Similarly, if less dramatically, Article 15a of the Austrian constitution provides: "The Federation and the Land can conclude agreements between themselves concerning matters of their current scope of competence." ${ }^{46}$ Such provisions formally institutionalize political rather than legal solutions to important constitutional questions, thereby diminishing the importance of subnational (or even national) constitutions as forums for public resolution of major issues.

44 Constitution of the Russian Federation, Art. 66(5).

45 G. Alan Tarr, Creating Federalism in Russia, 40 S. Tex. L. Rev. 689 (1999).

46 Federal Constitutional Law of Austria, Art. 15a(1). 
The subsidiarity theory of subnational power. In the United States, and subsequently elsewhere in the Americas, principles of federalism evolved from an eighteenth-century conceptual framework of natural rights in which even good government was seen as an inherently dangerous, potential enemy of popular liberty, and thus at best a necessary evil to be tolerated rather than a good to be affirmatively desired. ${ }^{47}$ From these premises, it followed that the primary goal of constitutional design was to construct a government capable of delivering a small number of indispensable benefits, while simultaneously adopting as many mutually reinforcing constraints on government as needed to confine it within the desired boundaries, thereby preventing it from fulfilling its potential for tyranny. Federalism served this purpose by pitting subnational power directly against national power in the form of an institutionalized competition between the state and national governments for popular loyalty. ${ }^{48}$ In the U.S. system, federalism therefore serves its purpose best when state and national power are allocated in such a way so that each level of government is capable in principle of fighting the other to a draw.

$47 \quad$ Madison, The Federalist, supra, No. 51: "But what is government itself, but the greatest of all reflections on human nature? If men were angels, no government would be necessary. If angels were to govern men, neither external nor internal controls on government would be necessary." 
Contemporary global federalism, particularly of the European variety, is rooted in very different soil and takes for itself very different objectives. Emerging from a post-World War II consensus that substantial national power is critical to the ultimate success of a state and to the prosperity of its citizens, European federalism conceives of the decentralization of power not as a mechanism for restraining the application of government power to the citizenry, but, on the contrary, as a mechanism for making the use of such powers more effective and efficient. This outlook is expressed in the constitutional principle of subsidiarity, which made its first appearance in Article 72 of the German constitution. Under the Basic Law, national power is divided into those powers that are exclusively national and those which may be exercised concurrently with the Länder. Under Article 72, however, the federal government may not employ its concurrent powers just because doing so seems desirable; it may invoke these powers only "if and insofar as the establishment of equal living conditions throughout the federal territory or the maintenance of legal or economic unity renders federal regulation necessary in the national interest." ${ }^{\text {49 }}$ In 1992, signatories of the Maastricht Treaty adopted the principle of subsidiarity for the newly restructured European Union. Article $3 \mathrm{~b}$ of the Treaty provides:

In areas which do not fall within its exclusive competence, the Community shall take action, in accordance with the principle of subsidiarity, only if and in so far as the objectives of the proposed action cannot be sufficiently achieved by the

49 Basic Law, Art. 72(2). This is the relevant text as amended in 1994. Before that amendment, the provision contained an even more explicit statement of the principle of subsidiarity: "The Federation shall have the right to legislate in these matters to the extent that a need for regulation by federal legislation exists because: (1) a matter cannot be effectively regulated by the legislation of the individual Länder, or (2) the regulation of a matter by a Land law might prejudice the interests of other Länder or of the people as a whole; or (3) the maintenance of legal or economic unity, especially by the maintenance of uniformity of living conditions beyond the territory of any one Land, necessitates such regulation." David P. Currie, The Constitution of the Federal Republic of Germany 43 (Chicago: University of Chicago Press 1994). 
Member States and can therefore, by reason of the scale of effects of the proposed action, be better achieved by the Community. ${ }^{50}$

According to these provisions, power in a regime of subsidiarity is allocated among levels of government so that it is exercised at the lowest possible level consistent with successful management of the problem addressed. As a result, power is to be exercised at the national level only when necessary to the achievement of collective goals. The principle of subsidiarity, then, limits the exercise of national power, but does so for distinctly non-Madisonian reasons. Power is allocated to subnational units in a subsidiarity regime not to make it available for deployment against national power, much less for the purpose of thwarting the achievement of national goals to which the subnational government objects, but because subnational power can under the circumstances accomplish nationally identified goals even more completely and effectively than can national power.

50 Treaty of European Union, Art. 3b. 
Power organized by subsidiarity thus contemplates a federalism that is cooperative rather than competitive. ${ }^{51}$ National and subnational units do not compete for the allegiance of the people by demonstrating their superiority in achieving popularly desired goals, but instead routinely yield to one another where the other's competence is objectively greater. Subsidiarity appeals not to the pragmatic, but to the rational; it rests not on the fear that governments will act aggressively to consolidate their power, but on the belief that they will, with proper guidance, pursue shared policies through optimal means. In a federalism based on subsidiarity, if national power threatens liberty, the threat does not arise from the mere use of power to displace private autonomy, but from inefficiency and bureaucratic incompetence caused by its inelegant use. emergence in Europe of the principle of subsidiarity. See, e.g., Morton Grodzins, The American System: A New View of Government in the United States (1966). 
Although subsidiarity has been constitutionally formalized only in Germany and the EU, it seems increasingly to be invoked as the dominant justification for federalism throughout the Union, ${ }^{52}$ a development that is in some tension with any perceived rise in subnational constitutionalism. Whereas subnational constitutionalism treats subnational units as independent popular agents with the autonomy to interpose themselves between the central government and the people, subsidiarity treats subnational units much more like administrative agents of the central state. Instead of exercising independent judgment about the wisdom and content of policy goals, subnational units in a regime of subsidiarity are understood to play mainly a collaborative role in implementing policy choices made by national consensus.

Supranational and international regimes as primary protectors of human rights. The most important justification by far for subnational constitutionalism is the benefit it confers in the protection of human rights. Instead of a single regime of rights protection implemented at the national level, subnational constitutionalism allows for the creation of a second, and to some degree competing, regime of rights protection at the subnational level. Subnational constitutionalism thus allows subnational units to use their autonomy to protect the rights of their citizens either by identifying and protecting rights in an enforceable subnational declaration of rights, or by using other powers so as to block rights-invading actions of the central authorities.

Although the recent proliferation of subnational constitutions containing express rights-protecting provisions might suggest a trend toward an emerging second layer of rights protection at the subnational level, this must be evaluated in light of another and conflicting

52 Subsidiarity has even been invoked as an organizing principle for national-subnational relations in unitary EU states such as Poland. See Ewa Poplawska, The Principle of Subsidiarity under the 1997 Constitution of Poland, 1997 St. Louis-Warsaw Transatlantic L.J. 107. 
recent trend: the emergence of a powerful and increasingly effective layer of rights protection at the supranational and international levels. Indeed, much of the existing evidence seems to suggest that in many parts of the world aggrieved groups and individuals seeking additional security for their human rights are more inclined to look upward, toward trans-national institutions, than they are to look downward, toward subnational institutions.

Any discussion of rights protection at the international level must begin with the United Nations, which since its founding has exercised undisputed world leadership in identifying and defining (if not in protecting and enforcing) those rights held in common by all human beings. U.N. conclusions concerning the content of human rights are widely accepted and command considerable deference, even to the extent that governments disinclined to respect U.N.-backed rights seem more likely to argue their contingent inapplicability than to dispute the substance of the rights on the merits. ${ }^{53}$ Some nations have even gone so far as to incorporate into their own constitutions the rights set out in United Nations documents. Article 75(22) of the Argentine constitution, for example, incorporates "at the same level as the Constitution" more than a half-dozen U.N.-sponsored conventions on human rights. ${ }^{54}$ Article 10(2) of the Spanish constitution provides: "The norms relative to basic rights and liberties which are recognized by

53 For example, one of the most serious challenges to the global human rights regime contemplated by the U.N., the "Asian Way" movement promoted by some east Asian governments, tends to argue not that U.N.-backed human rights are not universal, but that their enforcement against states must be tempered or modified in some circumstances so as to give proper weight to countervailing cultural norms (such as a desire for consensus) or economic contingencies (such as giving priority to economic development objectives). See, e.g., Asoka De Z Gunawardana, An Asian Perspective on Human Rights, 1994 Singapore Journal of Legal Studies 521; Michael Haas, The Asian Way to Peace: A Story of Regional Cooperation 2-10 (1989); Richard Klein, Cultural Relativism, Economic Development, and International Human Rights in the Asian Context, 9 Touro Int'l L. Rev. 1 (2001).

54 The Constitution of the Argentine Nation, Art. 75(22). The same provision permits repudiation of these conventions only upon agreement by the national executive and a two-thirds vote of the national legislature. 
[this] Constitution, shall be interpreted in conformity with the Universal Declaration of Human Rights and the international treaties and agreements on those matters ratified by Spain." ${ }^{.55}$

Although the source of the U.N.'s power to protect human rights comes more often from the dignity of its role as a definer of aspirations and the apparent appeal of its vision of universal human rights, it has occasionally moved beyond the hortatory to the actual enforcement of human rights. For example, the U.N. has played a role in policing the human rights of national minorities in places such as Kosovo and Bosnia and Herzegovina. 
At the supranational level, the EU's principal human rights document, the Convention for the Protection of Human Rights and Fundamental Freedoms, has since the recent consolidation of the EU also assumed a place as one of the world's most important sources of protection for human rights. Not only does the Convention specify and define numerous human rights, it links them to what has become an effective system of enforcement through the European Court of Human Rights $(\mathrm{ECHR})^{56}$ and the EU administrative apparatus. As a result, the ECHR routinely makes rulings regarding fairly significant official actions of member states, and the Court's interpretations of the Convention have on some occasions penetrated deeply into the operation even of the domestic political systems of member states. For example, in 2004 the Court invalidated a British law disenfranchising all prisoners serving life sentences, ${ }^{57}$ and in 2002 it upheld Turkey's dissolution of a religious political party. ${ }^{58}$

These developments suggest that in many places, and especially in Europe, it is possible that subnational units are unlikely to be viewed by either the public or by governmental actors as playing the kind of significant role in the protection of human rights that would indicate a robust subnational constitutionalism. It seems at least as likely that members of subnational groups who view their national government as a potential human rights scofflaw would turn to supranational or international organizations, rather than subnational ones, for enhanced

56 One commentator calls it "widely and rightly regarded as the most effective international human rights institution.” Paolo G. Carozza, Subsidiarity as a Structural Principle of Human Rights Law, 97 Am. J. Int'l L. 38,74 (2003).

57 Hirst v. United Kingdom (No. 2), No. 74025/01 (March 30, 2004).

58 Refah Partisi (The Welfare Party) v. Turkey, 35 Eur. H.R. Rep. 3 (2002). 
protection. To the extent this turns out to be the case, the possibility of subnational constitutionalism is correspondingly diminished.

Lack of a dual court system. In the United States, subnational constitutionalism is favored by the dual structure of the court system, in which each state and the national government has its own independent judiciary. In this system, each level of government has the final responsibility for interpreting its own constitution. Because state and national authority overlap in the U.S. federal structure, this arrangement has a tendency to put the national and subnational judicial systems into a kind of dialogue with one another, a dialogue carried on through judicial interpretation of constitutions at each level.

A prominent recent example concerned the authority of U.S. governments to impose criminal punishments for homosexual conduct. The Supreme Court of the United States initially interpreted the due process clause of the U.S. Constitution to permit criminal punishment by state governments of homosexual acts. ${ }^{59}$ This did not foreclose the possibility that state constitutions might nevertheless forbid states from imposing such punishment, and when that question was raised in the supreme courts of several states, they reached a contrary conclusion, holding that similar due process protections provided in the constitutions of their respective states prohibited criminalization of homosexual acts. ${ }^{60}$ These state decisions helped convince the U.S. Supreme Court to reconsider its earlier ruling, which it overruled in a later case. ${ }^{61}$ In this dialogic

\footnotetext{
59 Bowers v. Hardwick, 478 U.S. 186 (1986).

60 Jegley v. Picado, 80 S.W. 3d 332 (Ark. 2002); Powell v. State, 510 S.E.2d 18 (Ga. 1998); Gryczan v. State , 283942 P.2d 112 (Mont. 1997); Campbell v. Sundquist, 926 S.W.2d 250 (Tenn. App. 1996); Commonwealth v. Wasson, 842 S.W.2d 487 (Ky. 1992).

$61 \quad$ Lawrence v. Texas, 539 U.S. 558 (2003).
} 
process, then, state courts not only deployed the protections of state constitutions to attempt to mitigate harm caused by what they believed to be an error by the Supreme Court, but also engaged the Court in a public debate about the meaning of the liberties protected by U.S. constitutions. Such acts form the essence of well-functioning system of subnational constitutionalism.

In this respect, however, the United States is an extreme outlier: no other federal state has a fully developed, dual judicial system. Even in federal states such as Australia, Canada, and Switzerland, where the national constitution permits the erection of dual national and subnational court systems, such authority has not been exercised. ${ }^{62}$ In some other states, such as Mexico, subnational units have well-developed judicial systems, but national courts are supreme with respect to the interpretation not only of national constitutional law, but of subnational constitutional law as well. ${ }^{63}$ A dual court system is by no means essential to the emergence of subnational constitutionalism, but it is helpful. As a result, throughout most of the world subnational constitutions do not exist within the structural conditions most conducive to the emergence of a robust state constitutionalism.

\section{Conclusions}

\footnotetext{
62

Watts, supra note at 955 .

63 Under Article 14 of the Mexican Constitution, the national power of judicial review has been construed to extend to any allegedly incorrect interpretation of law by state courts, including state law. See Stephen Zamora and José Ramón Cossío, Mexican Constitutionalism after Presidencialismo, 4 Int'l J. Con. Law 411, 434-35 (2006).
} 
The spread of federalism, and the accompanying spread of subnational constitutions, offer a tempting leap of logic: that where there's smoke, there's fire - that the proliferation of subnational constitutions reflects a spreading belief in the efficacy of subnational power as a check on national power, and that this in turn implies a growing tendency around the globe to embrace subnational constitutionalism. The evidence, however, is mixed. Some aspects of the spread of subnational constitutions are consistent with an underlying ideology of subnational constitutionalism, but other factors suggest that such appearances may be deceiving. ${ }^{64}$

In searching for evidence of subnational constitutionalism, we must also remember that practices of constitutional self-governance can evolve, and it is always possible that changing political circumstances can cause corresponding changes in the ways that democratic polities make use of the constitutional structures they have created. So, for example, a sudden collapse in efficacy of supranational and international regimes of human rights protection could greatly increase demand for a well-functioning supplemental regime of rights protection at the subnational level. Or growth in the scale and intensity of subnational identity politics could redirect public trust from national to subnational governments, encouraging them to take on new roles or to exercise existing powers more aggressively.

Ultimately, substantial additional research is needed to determine how subnational power functions on the ground in the various federal states. Is it used in the ways contemplated by national and subnational constitutions? Do government officials work within the constitutional or sufficient condition for a federal political culture. Only in the United States and Switzerland do both the birth and subsequent modifications of state constitutions seem to offer a significant confirmation of federal political culture and a two-way traffic in federal practices between the federal and state governments." 
framework? Is there a struggle for dominance between national and subnational governments? If so, are subnational units capable of prevailing? To what extent do people identify with their national or subnational polities, and is this identity stable? No search for subnational constitutionalism will be very effective until such basic questions are addressed. 